\title{
The Research on the Training Mode of Mechanical Professionals Oriented by Job Demands under the Background of New Engineering
}

Yayun Jin, Yuanyuan Xu, Jianhua Xu, Ji Luo, Ningping Xu

Nantong University of Technology

Jin Yayun (1975 -), Female,Jiangsu Nantong,

Nantong University of Technology, School of Mechanical Engineering, Director of Mechanical Foundation Teaching a nd Research Office, Associate Professor, Engineer.

Project: 2018 jiangsu university philosophy and social science research project

Research on the training mode of applied mechanical talents under the background of "new engineering" (Number: 2018SJA1272)

Training Project of Scientific Research backbone for Middle-aged and Young people Nantong University of Technol ogy (Number: ZQNGG311)

Mechanical engineering" funded by key construction disciplines in jiangsuprovince (Jiangsu Education Research 2016] 9)

2018 jiangsu university philosophy and social science research project

Research on Teaching Reform of Applied Undergraduate Mechanical SpecialtiesServing Local Economy in New En gineering Environment(Number: 2018SJA1274)

Abstract: Based on the adjustment and development of the national economic structure, college education is separated from the actual needs of the society. Some problems are highlighted. For example, the update of teaching content is lagging behind, practical teaching cannot meet the needs of students, and professional teachers are insufficient. This paper first analyzes the current status of the training of mechanical professionals in colleges and universities, and explores the training mode of mechanical professionals oriented by job demands under the background of new engineering to provide the reference for the educators.

Keywords: New engineering; Job Demands; Mechanical Majors; Talent Training Mode

\section{Introduction}

Our country's social and economic development has continued to grow, and various national science and technology strategies have been continuously implemented, which has set a higher standard for college education to cultivate high-quality engineering and technical talents. From the perspective of professional disciplines, the construction of new engineering is a process of continuous updating and development of engineering teaching starting from practical teaching at the cognitive level. Therefore, the training of mechanical professionals should be effectively combined with social and economic needs, and professional education should be combined with industrial development. The construction and development of the country's emerging industries are inseparable from the continuous supply of university education talents. The country's future research, development and transformation of new technologies need more and more continuous support of high-level technical talents. The new economic industry is a powerful driving force for the cultivation of engineering technology talents in our country's universities.

Copyright $(2020$ Yayun Jin et al.

doi: $10.18282 /$ le.v9i4.1073

This is an open-access article distributed under the terms of the Creative Commons Attribution Non-Commercial License

(http://creativecommons.org/licenses/by-nc/4.0/), which permits non-commercial use, distribution, and reproduction in any medium, provided the original work is properly cited. 


\section{The current status of the cultivation of mechanical professionals in colleges and universities}

Mechanical majors can be called the strongest engineering subjects, and they have wide adaptability in the job market. Teaching in these majors emphasizes that the cultivation of talents should meet the needs of application-oriented senior professionals. However, the current position of colleges and universities on the training mode for mechanical talents is not clear, teaching resources are insufficient and the teaching design is unreasonable, resulting in insufficient professional practice ability of students, and the lack of organic combination of theoretical knowledge and practice in teaching, which leads to a large gap between students' theoretical knowledge and practical ability.

\section{The Research on the training mode of mechanical professionals oriented by job demands}

\subsection{Establish a talent training mechanism oriented by job demands}

The teaching of mechanical majors in colleges and universities should fully take the social economy and the needs of enterprises as the premise, reform the professional curriculum, optimize and adjust the content of professional teaching, actively establish a training mechanism for mechanical professionals oriented by job demands, strive to comply with the development of the market economy, ensure the close connection between professional talent training and market talent demands, professional teaching and industrial development, professional courses and counterpart posts, professional textbooks and professional skills, establish a talent training mechanism for mechanical majors in colleges and universities, and effective innovate professional talent training mode through in-depth school-enterprise cooperation.

\subsection{Cultivate the innovative ability and comprehensive ability of students of mechanical majors}

The training of mechanical professionals in colleges and universities must pay attention to the improvement of students' innovative ability and comprehensive literacy, so as to meet the all-round needs of the society for talents. For example, in the graduation design of students, colleges should strengthen their engineering practice ability. In the topic selection of graduation design, students are required to determine the target of selection according to their own personal business practice. Under the school-enterprise cooperation mode, the guidance of double tutors helps students in graduation design. Enterprise instructors are responsible for technical practice guidance, and college teachers are responsible for controlling the academic quality of thesis, which promotes the effective improvement of students' engineering practice ability. It not only solves the problem of insufficient practice teaching ability of universities, but also facilitates teachers to participate in enterprise engineering project research and jointly solve enterprise technology problem. At the same time, colleges and universities should pay attention to the development of students' innovation and entrepreneurship capabilities, and create a good atmosphere for innovation and entrepreneurship teaching, such as the establishment of mechanical innovation teaching laboratories, digital design laboratories, engineering technology simulation laboratories, to guide mechanical students to actively carry out scientific and technological innovation activities, irregularly organize students to participate in various engineering competitions. Students' creative ability can be stimulated through competitions, so as to effectively improve students' engineering literacy.

\subsection{Build a double-qualified teacher team through industry-university cooperation}

Teachers are the pioneers of imparting knowledge and skills. Today, with the rapid development of science and economy, talents engaged in engineering education must keep up with the needs of the era and constantly improve their business capabilities to meet the needs of social development. Therefore, in engineering education, teachers' professional quality of engineering is very important, and colleges and universities should strengthen the training of engineering teachers' professional teaching ability. First of all, colleges and universities must hire experts with rich engineering practical experience in the enterprise to engage in part-time teaching of mechanical professional teaching, arrange enterprise engineers and technical personnel to carry out professional exchange seminars, and establish a doublequalified teacher team; Secondly, colleges and universities should let young key teachers go to the enterprise's frontline to participate in engineering practice operations to enable engineering teachers to strengthen engineering practice ability, 
and integrate practical experience into theoretical knowledge teaching, improving teachers' comprehensive teaching ability; Finally, colleges and universities should form echelon construction in the faculty team, establish a mentoring education mechanism, and enable teachers with rich engineering practical experience to lead other teachers to carry out teaching activities, promoting the improvement of overall teaching ability.

\subsection{Colleges and universities should continue to explore the school-enterprise cooperation model}

School-enterprise cooperation is an important teaching model for the reform and development of college education. Through school-enterprise cooperation, information and resources are shared between schools and enterprises. Enterprises provide necessary teaching practice resources for colleges and universities, and at the same time solve the problem of professional talent training. College teaching organically combines theoretical knowledge with enterprise practice, so as to form a balance of interests and complementary advantages between the two and effectively save the cost of colleges and enterprises. Therefore, colleges and universities should actively seek suitable cooperative enterprises, and promote the establishment of a school-enterprise cooperation platform through local governments and industry associations, so as to effectively promote the professional talents training mechanism featuring teaching resource sharing, teaching process interaction and mutual benefit between schools and enterprises. In this process, the school-enterprise cooperation should be based on the cultivation of students' practical ability, with emphasis on the skill cultivation of mechanical talents. Both schools and enterprises should fully strengthen the education model of schoolenterprise cooperation, use the industry-university-research cooperation base to deepen the construction of teaching cooperation content, so that enterprises can benefit from it, and students can continuously improve their innovative and practical capabilities. At the same time, deep school-enterprise cooperation can effectively promote universities and enterprises to form a talent training mechanism of industry-education integration, allowing enterprises and universities to jointly participate in professional curriculum construction, practical training and teaching, jointly undertake the core teachings of professional theory and practice, jointly formulate student internship programs, and assist students in graduation design. Through a series of cooperative teaching, students can obtain comprehensive professional learning and personally obtain experience in production, so as to effectively train students' new engineering thinking and practical ability. Meanwhile, enterprises also obtain talent support and long-term development to achieve a win-win situation for both schools and enterprises.

\section{Conclusion}

Under the background of new engineering, new technologies and new ideas are emerging one after another, which brings huge opportunities and challenges to high-tech majors. Therefore, the cultivation of mechanical professionals must be oriented by job demands, establish a new curriculum system in line with engineering students, continuously improve their vocational skills and comprehensive literacy, strengthen the construction of double-qualified teachers in colleges and universities, improve the construction of practical training bases, deepen the school-enterprise cooperation model, comprehensively promote the reform of the teaching reform of mechanical majors, realize the educational goals that the teaching adapt to social needs, and the academy is closely related with employment, effectively improving the training quality of mechanical talents in colleges and universities, so as to deliver batches of application-oriented hightech talents to the country.

\section{References}

1. Zhou Dashuai/Tian Huimin/Jiang Wei. The Discussion on the Training Mode of Application-Oriented Talents in Mechanical Engineering under the Background of "New Engineering" [J]. Jiangsu Science and Technology Information,2019,36(33):59-61.

2. Wang Ping/Gao Gangyi. The Study on the Training Plan of Mechanical Professionals under the Background of New Engineering[J]. Southern Agricultural Machinery,2019, 50 (21):169-170.

3. Yang Zhi/ Zhang Chuanwei. The Research on the Reform of Mechanical Talent Cultivation Mode under the Background of New Engineering[J]. The Road to Success, 2019, (16):1. 